\title{
Hot Flashes and their Association with Carotid Intima Media Thickness in Midlife and Beyond
}

\author{
N. Hephzibah Kirubamani, Porchelvan Swaminathan and Meenakshi Murugappan \\ Obstetrics \&t Gynaecology, Saveetha Medical College, SIMATS Email: hepsi1002@yahoo.co.in
}

\section{ABSTRACT}

Recent evidence suggests that there is an association between menopausal hot flashes and cardiovascular risk. Higher Carotid Intima Media thickness (CIMT) associated with subclinical atherosclerosis Subclinical atherosclerosis is predictive of later coronary vascular disease. To study the association of hot flashes in perimenopause and postmenpause women with carotid intima media thickness. Cross sectional prospective observational study was conducted among women aged 40-55 at Saveetha Medical College Gynecology Department. After ethical clearance and informed consent was obtained, 120 participants were recruited. Perimenopause and menopause women with intact uterus with both ovaries were included. Exclusion criteria were, chronic medical diseases, cancer women on long term medication, and use of hormonal/hormone-like supplements. After routine examination, anthropometric measurement, fasting blood sample for serum estradiol on 2-5 days of a spontaneous menstrual cycle was taken. CIMT of left and right carotid artery at four locations was assessed with B mode USG Philips affinity 30 with 4-12mhz frequency transducer. To assess hot flashes, a questionnaire was given. Women were divided into one of three groups according to hot-flash status over the past three months, namely mild, moderate, and severe. Statistical analysis was done to correlate hot flashes with CIMT. Average age of women screened was 50.7 years. Perimenopausal women were 42.5\%, 32.5\% early post-menopausal women and 25\% late postmenopausal women. Mild hot flash in 55.8\%, moderate in 25.8\% and severe in 18.33\% Mean CIMT in mild hot flash group $0.61 \mathrm{~mm}+-0.08$, in moderate hot flash group $0.63+-0.11$ and in severe hot flash group $0.67+-0.12 \mathrm{~mm}$ with $\mathrm{p}$ value of 0.001 Seventy-five percentage of women who had severe hot flash were among BMI $>30$ and in $31.4 \%$ among perimenopause women. There is a positive correlation with severe hot flushers in obese and in perimenopausal women. The present study suggest that severe hot flashes are associated with increased CIMT in perimenopause and obese women. This findings may be a useful marker to provide risk stratification and can guide clinical care.

KEY WORDS: PERIMENOPAUSE, HOT FLASH, CARDIOVASCULAR, MENOPAUSE, CIMT, SUBCLINICAL ATHEROSCLEROSIS

\section{INTRODUCTION}

Hot flashes and night sweats are troublesome symptom which occur among perimenopause \&t postmenopausal women. Hot flashes and night sweats are known as Vasomotor symptoms (VMS). Carotid intima-media thickness (CIMT) is high among postmenopausal women with vasomotor symptoms. Evidence is conflicting regarding increased risk of cardiovascular disease among

Biosc Biotech Res Comm P-ISSN: 0974-6455 E-ISSN: 2321-4007

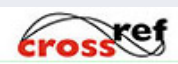

Identifiers and Pagination

Year: 2021 Vol: 14 No (9) Special Issue

Pages: $180-183$

This is an open access article under Creative

Commons License Attribn 4.0 Intl (CC-BY). DOI: http://dx.doi.org/10.21786/bbrc/14.9.34 postmenopausal women with hot flashes. Hot flashes and night sweats are surrogate markers of cardiovascular disease. Hot flashes and night sweats are associated with poor quality of life and one quarter of menopause women suffer from this. Though etiology of vasomotor symptoms has not been fully understood, it may be associated with changes in several organ and it may be a marker of coronary artery disease. There is an association with hot flashes and carotid artery with higher carotid intima media thickness (Rebecca et al., 2016).

Higher carotid intima media thickness associated with subclinical atherosclerosis which can be assessed by carotid ultrasound. Subclinical atherosclerosis is predictive of later coronary vascular disease. Carotid Intima Media thickness, plaque and calcification are indicator of later clinical CVD. Mostly hot flashes

\section{Article Information}

Received: $08^{\text {th }}$ May 2021 ccepted after revision: $14^{\text {th }}$ July 2021 
occurrence peaks in late perimenopause and early post menopause. Hypoestrogenic state associated with menopause involved in the physiology of hot flashes and associated with endothelial dysfunction (Kalantaridou et al., 2004).

Estrogen receptors ERs though stimulate endothelial cell growth but vascular smooth muscle proliferation inhibited (Koledova \& Khalil 2007) Though Hypoestrogenic state associated with hot flash there is no well documented evidence its response to hormone therapy (Barnabei et al., 2002) Effect of EPT on risk of CVD events among older postmenopausal women with significant hot flashes may increase risk of CVD event (Alison et., al 2009) When hormone therapy initiated to recent menopause women had reduced risk of CVD (Jacques et al., 2007) Several indices namely flow medicated dilation, coronary artery calcification and aortic calcification are associated with hot flashes and cardiovascular events were higher in subjects with flow mediated dilation (Joseph et al., 2007) Early atherosclerosis is a marker of endothelial dysfunction. Endothelial dysfunction is a cardiovascular risk factor (Michael et al., 2003). Hot flashes may be surrogate marker for underlying vascular changes in midlife women (Thurston RC et al., 2008).

Table 1. CIMT Measurements in Various Group
\begin{tabular}{c|c|c|c|c|}
\hline CIMT & $\begin{array}{c}\text { Mild Hot Flash } \\
(\mathrm{n}-67)\end{array}$ & $\begin{array}{c}\text { Moderate Hot Flash. } \\
(\mathrm{n}-31)\end{array}$ & $\begin{array}{c}\text { Severe Hot Flash } \\
(\mathrm{n}-22)\end{array}$ & p value \\
\hline Mean & $\begin{array}{c}0.61 \mathrm{~mm} \pm 0.08 \\
55.83 \%\end{array}$ & $\begin{array}{c}0.63 \mathrm{~mm} \pm 0.11 \\
25.83 \%\end{array}$ & $\begin{array}{c}0.67 \mathrm{~mm} \pm 0.12 \\
18.33 \%\end{array}$ & 0.001 \\
\hline
\end{tabular}

Higher IMT seen in severe Hot Flash women

Table 2. Presence of Plaque in Carotid Vessel in Various Groups (Cross tab \&t Chi square Tests)

\begin{tabular}{|c|c|c|c|c|c|}
\hline \multicolumn{6}{|c|}{ Plaque * Group Crosstabulation } \\
\hline & & \multicolumn{3}{|c|}{ Group } & \multirow[b]{2}{*}{ Total } \\
\hline & & Mild Hot flush & $\begin{array}{l}\text { Moderate } \\
\text { Hot flush }\end{array}$ & $\begin{array}{c}\text { Severe } \\
\text { Hotflush }\end{array}$ & \\
\hline \multirow[t]{2}{*}{ Plaque None } & Count & 67 & 27 & 15 & 109 \\
\hline & $\%$ within Plaque & $61.5 \%$ & $24.8 \%$ & $13.8 \%$ & $100.0 \%$ \\
\hline \multirow[t]{2}{*}{ Moderate } & Count & 0 & 4 & 7 & 11 \\
\hline & $\%$ within Plaque & $.0 \%$ & $36.4 \%$ & $63.6 \%$ & $100.0 \%$ \\
\hline \multirow[t]{2}{*}{ Total } & Count & 67 & 31 & 22 & 120 \\
\hline & $\%$ within Plaque & $55.8 \%$ & $25.8 \%$ & $18.3 \%$ & $100.0 \%$ \\
\hline
\end{tabular}

\begin{tabular}{|c|c|c|c|}
\hline \multicolumn{4}{|c|}{ Chi-Square Tests } \\
\hline & Value & $\mathrm{df}$ & $\begin{array}{l}\text { Asymp. Sig. } \\
\text { (2-sided) }\end{array}$ \\
\hline Pearson Chi-Square & $20.838^{a}$ & 2 & .000 \\
\hline Likelihood Ratio & 22.167 & 2 & .000 \\
\hline $\begin{array}{l}\text { Linear-by-Linear } \\
\text { Association }\end{array}$ & 20.437 & 1 & .000 \\
\hline $\mathrm{N}$ of Valid Cases & 120 & & \\
\hline
\end{tabular}

Moderate plaque was seen in moderate and severe Hot Flash women $\mathrm{Ct}$ it is statistically significant.

\section{MATERIAL AND METHODS}

This is a cross sectional prospective observational study comprised of 120 perimenopause and post menopause women. Women aged 40-55 years attending gynaec outpatient were included after ethical clearance and informed consent. Demographic details were collected. BMI was calculated for all women, and Blood pressure was taken in a sitting position after 10 minutes rest.
Participants were nonsmoker women with intact uterus with both ovaries who are in transition from perimenopause period to menopause and had at least 3 menstrual periods in the last 12 months and menopause more than 12 months amenorrhea. Women with chronic medical disease like diabetes, hypertension renal disease, pregnancy, hyperlipidemia, cancer, on long term medication, and use of hormonal/hormone-like supplements were excluded from studies. After routine examination anthropometric measurement, fasting blood sample for hormone assays on 2-5 days of a spontaneous menstrual cycle was taken.

Carotid Intima media Thickness of left and right carotid artery at four locations was assessed by certified sonographer with B mode USG Philips affınity 30 with 4-12 $\mathrm{MHz}$ frequency transducer. CIMT was measured at lumen interface and the media interface for $1 \mathrm{~cm}$. segments. When there is a distinct focal area protruding into vessel lumen $>50 \%$ thicker than adjacent IMT it is considered as plaque. Hot flashes were assessed by questionnaire. Women were divided into one of three groups according to hot-flash status over the past three months. Namely mild (Group A) moderate (Group B) and severe (Group C). Hot flash was graded as mild if women felt feeling of heat without sweating, moderate if women felt feeling of heat with sweating and severe if women felt feeling of heat with sweating, palpitation that disrupts usual activity. Object of the study is to evaluate association of hot flashes with subclinical atherosclerosis which is assessed by carotid intima media thickness.

\section{RESULTS AND DISCUSSION}

In this study the average age of the women screened was 50.7 and ranged between 40 to 55 years. Perimenopause 
women were 42.5\%(n - 51) and 32.5\% (n - 39) early menopause women (menopause within 1-5 years) and 25\% (n-30) late menopause women (menopause 5-10 years) were included in the study. BMI among women recruited were $57.5 \%(n-69)$ of them had BMI $<25$, twenty seven women - 22.5\% had BMI 26-29 and twenty-four women $-20 \%$ had BMI $>30$. In this study mean oestriol was $28 \mathrm{pg}$. Sixty seven- 55.83\% had mild hot flashes, 5.83\% (n-31) had moderate hot flashes and 18.33\% (n-22) had severe hot flashes. All analyses were performed using SPSS windows version 17. Associations between hot flash and carotid artery intimal thickness, Plaque, BMI and Menopausal status were evaluated using chi-square tests. Table 1 shows mean carotid artery intimal thickness among 67 mild hot flashes women was $0.61 \pm 0.08$ thirtyone moderate hot flashes women CIMT was $0.63 \pm 0.11$ and in twenty-two severe hot flashes women CIMT was $0.67 \pm 0.12$ with $p$ value 0.001 . Moderate Plaque was seen in $36.4 \%$ in moderate hot flash women, and in $63.6 \%$ in severe hot flash women.

Table 3. Correlation of Hot flash with BMI- (Cross tab \&t Chi square Tests)

\begin{tabular}{|c|c|c|c|c|c|c|}
\hline \multicolumn{7}{|c|}{ BMI * Group Crosstabulation } \\
\hline & & & \multicolumn{3}{|c|}{ Group } & \multirow[b]{2}{*}{ Total } \\
\hline & & & Mild Hot flush & $\begin{array}{l}\text { Moderate } \\
\text { Hot flush }\end{array}$ & $\begin{array}{l}\text { Severe } \\
\text { Hot flush }\end{array}$ & \\
\hline \multirow[t]{6}{*}{ BMI } & 25 & Count & 59 & 9 & 1 & 69 \\
\hline & & $\%$ within BMI & $85.5 \%$ & $13.0 \%$ & $1.4 \%$ & $100.0 \%$ \\
\hline & $28<<30$ & Count & 7 & 17 & 3 & 27 \\
\hline & & $\%$ within BMI & $25.9 \%$ & $63.0 \%$ & $11.1 \%$ & $100.0 \%$ \\
\hline & $>30$ & Count & 1 & 5 & 18 & 24 \\
\hline & & $\%$ within BMI & $4.2 \%$ & $20.8 \%$ & $75.0 \%$ & $100.0 \%$ \\
\hline \multirow[t]{2}{*}{ Total } & & Count & 67 & 31 & 22 & 120 \\
\hline & & $\%$ within BMI & $55.8 \%$ & $25.8 \%$ & $18.3 \%$ & $100.0 \%$ \\
\hline
\end{tabular}

\begin{tabular}{|c|c|c|c|}
\hline \multicolumn{4}{|c|}{ Chi-Square Tests } \\
\hline & Value & df & $\begin{array}{l}\text { Asymp. Sig. } \\
\text { (2-sided) }\end{array}$ \\
\hline Pearson Chi-Square & $99.226^{8}$ & 4 & .000 \\
\hline Likelihood Ratio & 92.839 & 4 & .000 \\
\hline $\begin{array}{l}\text { Linear-by-Linear } \\
\text { Association }\end{array}$ & 73.225 & 1 & .000 \\
\hline $\mathrm{N}$ of Valid Cases & 120 & & \\
\hline
\end{tabular}

Severe hot flash is seen in women BMI>30 and it is statistically significant.

Table 2 shows distribution of Plaque. There is significant statistical association with severe hot flash and Plaque at $\mathrm{p}$ value less than $<0.001$. Table 3 shows distribution of hot flash among different BMI group women. Seventy-five percentage of women who had severe hot flash were BMI $>30$. Table 3 show distribution hot flash among various Menopausal status. The correlation was done using chi -square tests. Statistical analysis revealed that severe hot flash was seen in $31.4 \%$ perimenopause women when compared with early and late menopause women with $\mathrm{p}$ value less than $<0.001$. interest systems. With the low misfit cost of power hydroelectric, the problem of minimizing the transition cost of a hydrothermal system basically reduces to that of minimize the fuel cost for thermal plants user the divers constraints on the hydraulic and power system grid.

Table 4. Correlation of Menopausal status and Hot Flash(Cross tab \&t Chi square Tests)

\begin{tabular}{|c|c|c|c|c|c|c|}
\hline \multicolumn{7}{|c|}{ Menopausal status * Severity of Hot flush Crosstabulation } \\
\hline & & & \multicolumn{3}{|c|}{ Severity of Hot flush } & \multirow[b]{2}{*}{ Total } \\
\hline & & & Mild Hot flush & $\begin{array}{l}\text { Moderate } \\
\text { Hot flush }\end{array}$ & $\begin{array}{l}\text { Severe } \\
\text { Hot flush }\end{array}$ & \\
\hline \multirow{6}{*}{$\begin{array}{l}\text { Menopausal } \\
\text { status }\end{array}$} & Perimenopause & Count & 14 & 21 & 16 & 51 \\
\hline & & $\begin{array}{l}\% \text { within } \\
\text { Menopausal status }\end{array}$ & $27.5 \%$ & $41.2 \%$ & $31.4 \%$ & $100.0 \%$ \\
\hline & Early Menopause & Count & 27 & 7 & 5 & 39 \\
\hline & & $\begin{array}{l}\text { \% within } \\
\text { Menopausal status }\end{array}$ & $69.2 \%$ & $17.9 \%$ & $12.8 \%$ & $100.0 \%$ \\
\hline & Late Menopause & Count & 28 & 3 & 1 & 30 \\
\hline & & $\begin{array}{l}\% \text { within } \\
\text { Menopausal status }\end{array}$ & $88.7 \%$ & $10.0 \%$ & $3.3 \%$ & $100.0 \%$ \\
\hline \multirow[t]{2}{*}{ Total } & & Count & 67 & 31 & 22 & 120 \\
\hline & & $\begin{array}{l}\% \text { within } \\
\text { Menopausal status }\end{array}$ & $55.8 \%$ & $25.8 \%$ & $18.3 \%$ & $100.0 \%$ \\
\hline
\end{tabular}

\begin{tabular}{|c|c|c|c|}
\hline \multicolumn{4}{|c|}{ Chi-Square Tests } \\
\hline & Value & df & $\begin{array}{l}\text { Asymp. Sig. } \\
\text { (2-sided) }\end{array}$ \\
\hline Pearson Chi-Squ & $31.278^{\mathrm{a}}$ & 4 & .000 \\
\hline Likelihood Ratio & 33.592 & 4 & .000 \\
\hline $\begin{array}{l}\text { Linear-by-Linear } \\
\text { Association }\end{array}$ & 25.952 & 1 & .000 \\
\hline$N$ of Valid Cases & 120 & & \\
\hline \multicolumn{4}{|c|}{$\begin{array}{l}\text { a. } 0 \text { cells }(.0 \%) \text { have expected count less than } \xi \\
\text { minimum expected count is } 5.50 \text {. }\end{array}$} \\
\hline
\end{tabular}

Recent evidence suggest there is a link between hot flashes and CVD risk indicators About 70\% of midlife women experience hot flashes. Hot flashes has impact on quality of women's life. Few trials suggest that women having moderate to severe hot flashes has CVD risk.( Thurston $\mathrm{RC}$ et al ). Women with Hot flashes may have an accelerated vasculature changes but it is due to aging or menopause is not yet explained. Since estrogen alters vasomotor stability Hot flashes and night sweats are considered as cardiovascular risk markers. Carotid intima thickness and plaque assessment predict changes in sub clinical atherosclerosis. Changes in subclinical atherosclerosis may be used as surrogate marker for cardiovascular risk. Hence this study aimed at association of hot flashes with subclinical atherosclerosis which is assessed by carotid intima media thickness.

Study by (Siobán \& Harlow 2020) 20\% of women reported hot flashes and night sweats while $~ 40 \%$ reported sleep disturbances 5- 10 years prior to FMP. In the study $31.4 \%$ perimenopause women had severe hot flashes. Hot flashes ranged from 22 to 55\% in the study by (Bastin et al., 2003) Study by concluded that Post-menopausal women with hot flashes had higher CIMT. In the study perimenopause women those who had severe hot flashes associated with increased CIMT and plaque which highlights its association with subclinical atherosclerosis. Hence midlife vasomotor symptoms may be marker for cardiovascular risk and it is a critical window for cardiovascular prevention in women. SWAN 
study by Nanette Santoro et al reported that elevated subclinical CVD and increased IMT, diminished flow mediated dilation, aortic calcification were among every day hot flashes women. In the study hot flashes were severe among women with BMI $>30$ and study by (Rebecca C et al., 2011) there is a correlation between hot flashes and overweight and obese women. Study by GailA concluded that women may be benefitted from vasomotor symptoms if they maintain ideal body weight Lifestyle modification may reduce vasomotor symptoms.

\section{CONCLUSION}

In the study increased Carotid artery intimal thickness were seen in perimenopause women with severe hot flashes and women with BMI $>30$. Hot flashes may be a marker for adverse cardiovascular changes and it gives window of opportunity to counsel them regarding life style modification and assess the other risk factors for CVS and prevent before clinical events.

\section{ACKNOWLEDGEMENTS}

I thank our Director Dr. Saveetha Rajesh and Dean Dr.Damotharan for the constant support and encouragement in conducting the study

\section{REFERENCES}

Alison J Huang, Sawaya GF, Vittinghoff E, Lin F, Grady D. (2009). Hot flushes, coronary heart disease, and hormone therapy in postmenopausal women. Menopause.; 16:639-643. [PubMed: 19325499]

Barnabei VM, Grady D, Stovall DW, Cauley JA, Lin F, Stuenkel CA Stefanick ML, Pickar JH. (2002) Menopausal symptoms in older women and the effects of treatment with hormone therapy. Obstet Gynecol.; 100:1209-1218.

Bastian LA, Smith CM, Nanda K. (2003). Is this woman perimenopausal? JAMA; 289:895-902. [PubMed: 12588275
Jacques Rossouw E, Prentice RL, Manson JE, Wu L, Barad D, Barnabei VM, et al. (2007). Postmenopausal hormone therapy and risk of cardiovascular disease by age and years since menopause. JAMA.; 297:14651477. [PubMed: 17405972]

Joseph Yeboah J, Crouse JR, Hsu FC, Burke GL, Herrington DM. Brachial, (2007). -mediated dilation predicts incident cardiovascular events in older adults: The Cardiovascular Health Study. Circulation.; 115:2390-2397

Kalantaridou SN, Naka KK, Papa Nikolaou E, Kazakos N, Kravariti M, Calis KA, Paraskevaidis EA, Sideris DA, Tsatsoulis A, Chrousos GP, Michalis LK. (2004). Impaired endothelial function in young women with premature ovarian failure: normalization with hormone therapy. J Clin Endocrinol Metab.; 89:3907-3913

Michael E Widlansky Gokce N, Keaney JF Jr, Vita JA. (2003). The clinical implications of endothelial dysfunction. J Am Coll Cardiol.;42: 1149-1160.

Rebecca et al, Yue fang Chang Emma Barinas- Mitche J. Richard Jennings, Doug P. Landsittel, Nanette Santoro, Roland von Känel, Karen A. Matthews, (2016). Menopausal Hot Flashes and Carotid Intima Media Thickness among Midlife Women, Journal of Stroke. December; 47(12)

Siobán D. Harlow, R. Elliott, Bondarenko, Rebecca C. Thurston, Elizabeth A. Jackson (2020). Monthly variation of hot flashes, night sweats and trouble sleeping: Effect of season and proximity to the Final Menstrual Period (FMP) in the SWAN Menstrual Calendar sub study: Menopause. January; 27(1): 5-13.

Thurston RC, Sutton-Tyrrell K, Everson-Rose SA, Hess R, Matthews KA. (2008). Hot flashes and subclinical cardiovascular disease: Findings from the study of women's health across the nation heart study. Circulation.; 118:1234-1240. [PubMed: 18765392] Vera V Koledova, Raouf A Khalil (2007).: Sex hormone replacement therapy and modulation of vascular function in cardiovascular disease: Expert Rev Cardiovasc Ther : Jul :5 (4) : 777-89 